\title{
Optimisation of Benzodiazepine Immunoassay Using $\beta$-Glucuronidase Enzymatic Hydrolysis: $A$ Comparison of Five Different $\beta$-Glucuronidase Enzymes
}

\author{
Ashraf Mina1,2*, Leah McNeice1, Shanmugam Banukumar'1, Santiago Vazquez \\ ${ }^{1}$ NSW Health Pathology, Forensic \& Analytical Science Service (FASS), Toxicology Unit, Macquarie Hospital, Sydney, Australia \\ ${ }^{2}$ Affiliated Senior Clinical Lecturer, Faculty of Medicine and Health, Sydney University, Sydney, Australia \\ Email: *ashraf.mina@health.nsw.gov.au
}

How to cite this paper: Mina, A., McNeice, L., Banukumar, S. and Vazquez, S. (2022) Optimisation of Benzodiazepine Immunoassay Using $\beta$-Glucuronidase Enzymatic Hydrolysis: A Comparison of Five Different $\beta$-Glucuronidase Enzymes. Journal of Biosciences and Medicines, 10, 7-15.

https://doi.org/10.4236/jbm.2022.101002

Received: November 24, 2021

Accepted: January 7, 2022

Published: January 10, 2022

Copyright $\odot 2022$ by author(s) and Scientific Research Publishing Inc. This work is licensed under the Creative Commons Attribution International License (CC BY 4.0).

http://creativecommons.org/licenses/by/4.0/

(c) (i) Open Access

\begin{abstract}
Background: Hydrolysis improves the sensitivity of drug detection for drug classes such as opiates/opioids and benzodiazepines, which are highly metabolized by glucuronidation and sulfation and should be implemented in analytical procedures to convert conjugated metabolites into the free or unbound form. This study was aimed to compare different enzymes to make an informed decision. Methods: In this study, the CEDIA Benzodiazepine assay was compared with the LC-MS-MS method using 150 positive urine samples and 50 negative urine samples. The samples were analysed without adding any enzyme and then by adding different enzymes to compare their performance. Results: The Kura Escherichia coli enzyme performed better than the Roche Escherichia coli enzyme which had 20\% false-positive results. Kura BG-100 enzyme performed well but Kura B-One enzyme performed better The Kura B-One enzyme had only $11.5 \%$ false-positive results. When double the volume of Kura B-One enzyme was used to test to see if it will have any impact on reducing the number of false negatives, it performed worse. Kura Turbo enzyme behaved similarly to Kura BG-100. Conclusions: The $\beta$-glucuronidase enzymes comparison allowed us to identify the Kura B-One enzyme as the enzyme of choice for our operation because it reduces the false positives from $20 \%$ to $11.5 \%$ when compared with the Roche enzyme. It also improved the detection of oxazepam. The Kura B-One enzyme has a short incubation time for hydrolysis when used with the LC-MS-MS method. As a result, we improved the overall turn-around time and reduced the number of false positives that needed confirmation.
\end{abstract}




\section{Keywords}

$\beta$-Glucuronidase Enzyme, CEDIA, Benzodiazepine, 7-Amino Clonazepam, 7-Amino Clonazepam

\section{Introduction}

Using $\beta$-glucuronidase is a preferred method of hydrolysis over acid-catalysed hydrolysis, which is known to induce benzodiazepine degradation and transformation to increase cross-reactivity [1] [2] [3]. Metabolised forms of benzodiazepines undergo a process called glucuronidation during metabolism that attaches a glucuronic acid for increased solubility [4] [5]. $\beta$-glucuronidase is an enzyme that is used to de-conjugate $\beta$-glucuronides during urinary drug testing for benzodiazepines. Hydrolysis improves the sensitivity of drug detection for drug classes such as opiates/opioids and benzodiazepines, which are highly metabolized by glucuronidation and sulfation and should be implemented in analytical procedures to convert conjugated metabolites into the free or unbound form. Enzyme hydrolysis of urine using the $\beta$-glucuronidase to liberate conjugated drugs improves detectability [6] [7]. Only trace amounts of parent benzodiazepines are present in urine following extensive metabolism and conjugation [8]. It is also important to understand the difference between different immunoassays methods and what they can detect and if there are any limitations [9]. The Thermo Fisher CEDIA high sensitivity assay performed better when compared to other immunoassays [10] [11]. This study compared five different enzymes with the CEDIA immunoassay. The enzymes tested are $\beta$-glucuronidase from Escherichia coli from Roche and four different enzymes are obtained from Finden Kura which are B-One $\beta$-Glucuronidase, BG-100 $\beta$-Glucuronidase, BG Turbo $\beta$-Glucuronidase, and $\beta$-Glucuronidase from Escherichia coli.

\section{Materials and Methods}

A total of 200 urine samples were tested for Benzodiazepine without adding enzyme and then tested separately after adding different enzymes. The 200 urine samples had 150 positive samples and 50 negative samples. The method used in this study was CEDIA ${ }^{\circledR}$ Benzodiazepine assay from Thermo Fisher (Catalogue number 1775561). The samples were tested using the Beckman-Coulter 5810 chemistry analyser. All results were confirmed using Liquid Chromatography with tandem mass spectrometry (LC-MS/MS). $\beta$-glucuronidase from Escherichia coli was obtained from Roche (Catalogue number 127680), B-One $\beta$-Glucuronidase was obtained from Finden Kura (Catalogue number B-One-10 mL), BG-100 $\beta$-Glucuronidase was obtained from Finden Kura (Catalogue number BG100-10 $\mathrm{mL}), \beta$-glucuronidase from Escherichia coli was obtained from Finden Kura (Catalogue number EBG), BG Turbo $\beta$-Glucuronidase was obtained from Finden Kura (Catalogue number BG Turbo-25 mL). Phosphate Buffer Saline was 
obtained from Thermo Fisher (Catalogue number TM4121).

Roche enzyme Escherichia coli which has the $\beta$-glucuronidase activity of $\geq 200$ $\mathrm{U} / \mathrm{mL}$ is validated and recommended by Thermo Fisher to be used with the CEDIA Benzodiazepine assay. Because the concentrations of $\beta$-glucuronidase enzymes and their origin are different, an equivalent concentration of glucuronidase activity of $200 \mathrm{U} / 1$ is used to test and compare all other enzymes using phosphate buffer saline to prepare the required concentration to maintain the optimum $\mathrm{pH}$ of the assay and the enzymes which are $\mathrm{pH}$ 7. The ratio of the enzyme added is about $5 \mu \mathrm{L}$ glucuronidase activity of $200 \mathrm{U} / \mathrm{L}$ to each $1 \mathrm{~mL}$ of the CEDIA reagent 1 . If a $\beta$-glucuronidase enzyme is added at a higher concentration that will lead to a lot of false-positive results and changes in the dynamics of the reactions. For some enzymes, the concentration is expressed as PS-U/mL. PS-U is a product-specific unit and identifies as "One Product Specific Unit will liberate $1.0 \mu \mathrm{g}$ of phenolphthalein from phenolphthalein glucuronide in $5 \mathrm{~min}$ utes at pH 6.8 and $20^{\circ} \mathrm{C}$ '. On chemistry analysers, it is not always possible to change the incubation time of a reaction as it is linked to the other mechanics that make the analyser fast and robust. In the case of the Beckman-Coulter chemistry analyser, the incubation time is fixed at 3.3 minutes when the tested sample is added to reagent number 1 of the assay.

In this study, the CEDIA Benzodiazepine assay was compared with LC-MS-MS using 150 positive urine samples and 50 negative urine samples. The samples were analysed without adding any enzyme and also after making different preparation with 5 different enzymes to compare how they perform.

\section{Results}

The Kura Escherichia coli enzyme performed better than the Roche Escherichia coli enzyme which had $20 \%$ false-positive results. The false negatives were less when the Roche enzyme was used only because the false positives were much higher because the Roche enzyme elevated all the baseline of results in general. Kura BG-100 enzyme performed well but Kura B-One enzyme performed better. The Kura B-One enzyme had only $11.5 \%$ false-positive results. Consequently, the true negatives were better when the Kura B-One enzyme was used. When double the volume of Kura B-One enzyme was added to test if it will have any impact on reducing further the number of false negatives, it performed worse. Kura Turbo enzyme behaved similarly to Kura BG-100. The results are summarised in Table 1.

The false negatives were mainly 7-Amino Clonazepam, 7-Aminonitrazepam and oxazepam. They were detected, but not up to the cut-off level to be reported as positive. Using the Kura B-One enzyme improved the detectability and the reporting of oxazepam only. According to the manufacturer, CEIA immunoassay cross-reactivity for 7 -Amino Clonazepam is $39 \%$ at a concentration of 515 $\mathrm{ng} / \mathrm{mL}$ and the cross-reactivity for 7 -Aminonitrazepam is $44 \%$ at a concentration of $450 \mathrm{ng} / \mathrm{mL}$ as shown in Table 2. 
Serial dilutions of 7-Amino Clonazepam and 7-Aminonitrazepam standard materials were tested using the Kura BG100 and Kura B-One enzymes. The cross-reactivity and consequently detectability was improved at a concentration of $62.5 \mathrm{ng} / \mathrm{mL}$ for 7-Amino Clonazepam and 7-Aminonitrazepam as shown in Table 3.

Table 1. Comparing CEDIA Benzodiazepine assay using five different enzymes with LC-MS-MS.

\begin{tabular}{|c|c|c|c|c|}
\hline $\begin{array}{l}\text { Comparison Between CEDIA Benzodiazepine Immunoassay } \\
\text { and LC-MS/MS Using Different Enzymes }\end{array}$ & $\begin{array}{c}\text { True } \\
\text { Positives }\end{array}$ & $\begin{array}{c}\text { True } \\
\text { Negatives }\end{array}$ & $\begin{array}{c}\text { False } \\
\text { Positives }\end{array}$ & $\begin{array}{c}\text { False } \\
\text { Negatives }\end{array}$ \\
\hline Without using any enzyme & 123 & 49 & 21 & 7 \\
\hline Escherichia coli enzyme (from Roche) & 127 & 31 & 40 & 2 \\
\hline Escherichia coli enzyme (from Kura) & 122 & 49 & 22 & 7 \\
\hline BG-100 enzyme (from Kura) & 123 & 49 & 22 & 6 \\
\hline B-One enzyme (from Kura) & 124 & 48 & 23 & 5 \\
\hline Double the volume of B-One enzyme (from Kura) & 122 & 45 & 26 & 7 \\
\hline Turbo enzyme (from Kura) & 123 & 49 & 22 & 6 \\
\hline
\end{tabular}

Table 2. Cross-reactivity of Benzodiazepine and metabolites-High Sensitivity at $200 \mathrm{ng} / \mathrm{mL}$ Cut-off level.

\begin{tabular}{|c|c|c|c|}
\hline Benzodiazepines and metabolites & Tested Concentration (ng/mL) & Positive/Negative & Cross-reactivity (\%) \\
\hline$\alpha$-Hydroxyalprazolam & 110 & Positive & 182 \\
\hline$a$-Hydroxytriazolam & 140 & Positive & 143 \\
\hline Alprazolam & 100 & Positive & 200 \\
\hline 7-Aminoclonazepam & 800 & Positive & 25 \\
\hline 7-Aminoflunitrazepam & 225 & Positive & 89 \\
\hline 7-Aminonitrazepam & 500 & Positive & 40 \\
\hline Bromazepam & 300 & Positive & 67 \\
\hline Chlordiazepoxide & 2000 & Positive & 10 \\
\hline Clobazam & 450 & Positive & 44 \\
\hline Clonazepam & 350 & Positive & 57 \\
\hline Clorazepate & 100 & Positive & 200 \\
\hline Delorazepam & 100 & Positive & 200 \\
\hline Demoxepam & 1500 & Positive & 13 \\
\hline Desalkylflurazepam (Norfludiazepam) & 110 & Positive & 182 \\
\hline Diazepam & 80 & Positive & 250 \\
\hline Estazolam & 115 & Positive & 174 \\
\hline Flunitrazepam & 125 & Positive & 160 \\
\hline Flurazepam & 70 & Positive & 286 \\
\hline Lorazepam & 250 & Positive & 80 \\
\hline Lorazepam glucuronide & 400 & Positive & 50 \\
\hline Lormetazepam & 175 & Positive & 114 \\
\hline
\end{tabular}


Continued

$\begin{array}{cclc}\text { Medazepam } & 200 & \text { Positive } & 100 \\ \text { Nitrazepam } & 290 & \text { Positive } & 69 \\ \text { Nordiazepam (Desmethyldiazepam) } & 70 & \text { Positive } & 286 \\ \text { Oxazepam } & 200 & \text { Positive } & 100 \\ \text { Oxazepam glucuronide } & 350 & \text { Positive } & 57 \\ \text { Prazepam } & 140 & \text { Positive } & 143 \\ \text { Temazepam } & 130 & \text { Positive } & 154 \\ \text { Temazepam glucuronide } & 250 & \text { Positive } & 80 \\ \text { Triazolam } & 90 & \text { Positive } & 222\end{array}$

Table 3. Cross-reactivity of 7-Amino Clonazepam and 7-Aminonitrazepam using Kura BG-100 enzyme and Kura B-One enzyme (Cut-off-200 ng/mL).

\begin{tabular}{|c|c|c|c|c|c|c|c|}
\hline \multicolumn{4}{|c|}{ Kura BG-100 enzyme } & \multicolumn{4}{|c|}{ Kura B-One enzyme } \\
\hline $\begin{array}{l}\text { Serial of Standard } \\
\text { Dilution }\end{array}$ & Drug & $\begin{array}{c}\text { LC-MS-MS } \\
\mathrm{ng} / \mathrm{mL}\end{array}$ & $\begin{array}{l}\text { CEDIA } \\
\mathrm{ng} / \mathrm{mL}\end{array}$ & $\begin{array}{c}\text { Serial of } \\
\text { Standard Dilution }\end{array}$ & Drug & $\begin{array}{c}\text { LC-MS-MS } \\
\mathrm{ng} / \mathrm{mL}\end{array}$ & $\begin{array}{l}\text { CEDIA } \\
\mathrm{ng} / \mathrm{mL}\end{array}$ \\
\hline 1 & \multirow{7}{*}{$\begin{array}{c}\text { 7-Aminonitra } \\
\text { zepam }\end{array}$} & 2500 & 649 & 1 & \multirow{7}{*}{$\begin{array}{l}\text { 7-Aminonitr } \\
\text { azepam }\end{array}$} & 2500 & 624 \\
\hline 2 & & 1250 & 618 & 2 & & 1250 & 576 \\
\hline 3 & & 500 & 500 & 3 & & 500 & 458 \\
\hline 4 & & 250 & 399 & 4 & & 250 & 379 \\
\hline 5 & & 125 & 331 & 5 & & 125 & 307 \\
\hline 6 & & 62.5 & 218 & 6 & & 62.5 & 216 \\
\hline 7 & & 31.25 & 168 & 7 & & 31.25 & 158 \\
\hline 8 & \multirow{7}{*}{$\begin{array}{c}\text { 7-Amino } \\
\text { Clonazepam }\end{array}$} & 2500 & 646 & 8 & \multirow{7}{*}{$\begin{array}{c}\text { 7-Amino } \\
\text { Clonazepam }\end{array}$} & 2500 & 623 \\
\hline 9 & & 1250 & 578 & 9 & & 1250 & 531 \\
\hline 10 & & 500 & 456 & 10 & & 500 & 419 \\
\hline 11 & & 250 & 375 & 11 & & 250 & 352 \\
\hline 12 & & 125 & 302 & 12 & & 125 & 273 \\
\hline 13 & & 62.5 & 215 & 13 & & 62.5 & 218 \\
\hline 14 & & 31.25 & 149 & 14 & & 31.25 & 159 \\
\hline
\end{tabular}

\section{Discussion}

Studies comparing CEDIA and EMIT immunoassay methods with LC-MS/MS method disputed specificity with no data regarding the false-positive and without specifying the metabolites [9] [12] [13]. Another study stated that the rates of enzyme hydrolysis depend on the configuration of the substrate as well as on the enzyme preparation used. The rate of cleavage was highest with the (S)-(+)glucuronide and $\beta$-glucuronidase from Escherichia coli. This enzyme possesses the highest degree of stereoselectivity; it hydrolyses the (S)-(+)-isomer more than 400 times faster than the (R)-(-)-form. Bovine liver glucuronidase is less 
stereoselective, whereas glucuronidase preparations of molluscan origin exhibit little stereoselectivity. The ready hydrolysis of one of the glucuronides by an enzyme from an intestinal microorganism may play a role in the enterohepatic circulation of oxazepam [14]. Enzyme preparations from Escherichia coli, Helix pomatia, and Patella vulgate were examined and found capable of reducing oxazepam or oxazepam glucuronide into nordiazepam (desmethyldiazepam). Nordiazepam formation was positively correlated with incubation temperature, incubation time, oxazepam concentration, and enzyme concentration. A study found that enzymatic hydrolysis using $\beta$-glucuronidase enzymes (Escherichia coli, Helix pomatia, and Patella vulgate) caused $<2.5 \%$ nordiazepam formation that was relative to the amount of oxazepam present in the system [15]. This unusual reductive transformation also occurs in other benzodiazepines with a hydroxyl group at the $\mathrm{C} 3$ position and converting temazepam into diazepam and lorazepam into delorazepam by about $1 \%$ [16]. These findings are suggesting the detection of nordiazepam, diazepam or delorazepam in biological samples subjected to testing involving enzyme-catalyzed hydrolysis should be interpreted with care. Another study found that after enzymatic hydrolysis of the urine samples, a 2 - 19-fold increase in the concentration of the designer benzodiazepines flubromazolam was found, highlighting the value of hydrolysis for this analyte [17]. It was shown in another study that the amount of 7-amino-flunitrazepam metabolite quantitated by GC-MS, however, accounted for only $15 \%-20 \%$ of the total OnLine immunoassay crossreactive flunitrazepam metabolites [18]. Another study evaluated EMIT, EPIA, and Online immunoassays with the GC-MS method and although differences in the performances of the investigated assay systems were observed, they all seem appropriate for clinical use in detecting benzodiazepine intake in drug abusers when enzymatic hydrolysis is included [19].

In this study, the Roche enzyme has $20 \%$ false-positive results, while the Kura B-One enzyme has $11.5 \%$ false positive. Consequently, the true negative was improved when using Kura B-One. In our laboratory, all positive results are retested by LC-MS-MS for confirmation. Using an enzyme that doesn't produce lots of false positives, reduce the unnecessary testing for confirmation which also improves the turn-around time for reporting. Because all negative results are reported without confirmation, false negatives constitute a problem in failing to report drug use. Analysing the results from LC-MS/MS for false-negative samples showed that the Kura B-One enzyme improves the detectability of oxazepam. Kura BG-100 and Kura B-One enzymes performed better than the other enzymes in detecting 7-Amino Clonazepam and 7-Aminonitrazepam at a cut-off level of $200 \mathrm{ng} / \mathrm{mL}$. Both of these drugs are detected through their cross-reactivity with the assay. There are methods described to measure 7-aminonitrazepam using HPLC also [20]. The prospects of this study should help other laboratories to choose an enzyme that suits their needs and workflow. Also to realise the differences between these enzymes. 


\section{Conclusion}

The $\beta$-glucuronidase enzyme comparison allowed us to identify the Kura B-One enzyme as the enzyme of choice for our operation because it reduces the false positives from $20 \%$ to $11.5 \%$ when compared with the Roche enzyme. As a result, the number of samples that need to go for confirmation on LC-MS-MS was reduced. It also improved the detection of oxazepam, 7-Amino Clonazepam and 7-Aminonitrazepam. Additionally, it has the least incubation time for hydrolysis when also used for confirmation using LC-MS/MS method which improved the overall turn-around time.

\section{Conflicts of Interest}

The authors declare no conflicts of interest regarding the publication of this paper.

\section{References}

[1] Johnson-Davis, K.L. (2018) Opiate \& Benzodiazepine Confirmations: To Hydrolyze or Not to Hydrolyze is the Question. Journal of Applied Laboratory Medicine, 2, 564-572. https://doi.org/10.1373/jalm.2016.022947

[2] Dou, C., Bournique, J.S., Zinda, M.K., Gnezda, M., McNally, A.J. and Salamone, S.J. (2001) Comparison of the Rates of Hydrolysis of Lorazepam-Glucuronide, Oxazepam-Glucuronide and Tamazepam-Glucuronide Catalyzed by E. coli Beta-D-Glucuronidase Using the On-Line Benzodiazepine Screening Immunoassay on the Roche/Hitachi 917 Analyzer. Journal of Forensic Sciences, 46, 335-340.

[3] Meatherall, R. and Fraser, A.D. (1998) Comparison of Four Immunoassays for the Detection of Lorazepam in Urine. Therapeutic Drug Monitoring, 20, 673-675. https://doi.org/10.1097/00007691-199812000-00016

[4] Taylor, L.L., Flint, N.A., Ma, V., Hill, B.M., Clark, C.J. and Strathmann, F.G. (2017) Internal Hydrolysis Indicator for Sample Specific Monitoring of $\beta$-Glucuronidase Activity. Journal of Analytical Toxicology, 41, 407-411. https://doi.org/10.1093/jat/bkx027

[5] Meatherall, R.C. and Fraser, A.D. (1998) CEDIA dau Benzodiazepine Screening Assay: A Reformulation. Journal of Analytical Toxicology, 22, 270-273. https://doi.org/10.1093/jat/22.4.270

[6] Beck, O., Lafolie, P., Odelius, G. and Boreus, L.O. (1990) Immunological Screening of Benzodiazepines in Urine: Improved Detection of Oxazepam Intake. Toxicology Letters, 52, 7-14. https://doi.org/10.1016/0378-4274(90)90160-N

[7] Fenton, J., Schaffer, M., Chen, N.W. and Bermes Jr., E.W. (1980) A Comparison of Enzyme Immunoassay and Gas Chromatography/Mass Spectrometry in Forensic Toxicology. Journal of Forensic Sciences, 25, 314-319.

[8] Morris, A.A., Chester, S.A., Strickland, E.C. and McIntire, G.L. (2014) Rapid Enzymatic Hydrolysis Using a Novel Recombinant $\beta$-Glucuronidase in Benzodiazepine Urinalysis. Journal of Analytical Toxicology, 38, 610-614. https://doi.org/10.1093/jat/bku083

[9] Mina, A. (2020) Comparison of Several Immunoassays Used in Drugs of Abuse Screening: Assessment against Gold Standard Methods and Calculation of Measurement Uncertainty. Journal of Pharmacological and Toxicological Methods, 101 Article ID: 106649. https://doi.org/10.1016/j.vascn.2019.106649 
[10] DeRienz, R.T., Holler, J.M., Manos, M.E., Jemionek, J. and Past, M.R. (2008) Evaluation of Four Immunoassay Screening Kits for the Detection of Benzodiazepines in Urine. Journal of Analytical Toxicology, 32, 433-437. https://doi.org/10.1093/jat/32.6.433

[11] Borrey, D., Meyer, E., Duchateau, L., Lambert, W., Van Peteghem, C. and De Leenheer, A. (2002) Enzymatic Hydrolysis Improves the Sensitivity of Emit Screening for Urinary Benzodiazepines. Clinical Chemistry, 48, 2047-2049.

https://doi.org/10.1093/clinchem/48.11.2047

[12] Darragh, A., Snyder, M.L., Ptolemy, A.S. and Melanson, S. (2014) KIMS, CEDIA, and HS-CEDIA Immunoassays Are Inadequately Sensitive for Detection of Benzodiazepines in Urine from Patients Treated for Chronic Pain. Pain Physician, 17, 359-66.

[13] Dixon, R.B., Floyd, D. and Dasgupta, A. (2015) Limitations of EMIT Benzodiazepine Immunoassay for Monitoring Compliance of Patients with Benzodiazepine Therapy Even after Hydrolyzing Glucuronide Metabolites in Urine to Increase Cross-Reactivity: Comparison of Immunoassay Results with LC-MS/MS Values. Therapeutic Drug Monitoring, 37, 137-139. https://doi.org/10.1097/FTD.0000000000000117

[14] Ruelius, H.W., Tio, C.O., Knowles, J.A., McHugh, S.L., Schillings, R.T. and Sisenwine, S.F. (1979) Diastereoisomeric Glucuronides of Oxazepam. Isolation and Stereoselective Enzymic Hydrolysis. Drug Metabolism \& Disposition, 7, 40-43.

[15] Fu, S., Lewis, J., Wang, H., Keegan, J. and Dawson, M. (2010) A Novel Reductive Transformation of Oxazepam to Nordiazepam Observed during Enzymatic Hydrolysis. Journal of Analytical Toxicology, 34, 243-251. https://doi.org/10.1093/jat/34.5.243

[16] Fu, S., Molnar, A., Bowron, P., Lewis, J. and Wang, H. (2011) Reduction of Temazepam to Diazepam and Lorazepam to Delorazepam during Enzymatic Hydrolysis. Analytical and Bioanalytical Chemistry volume, 400, 153-164. https://doi.org/10.1007/s00216-011-4723-y

[17] Pettersson Bergstrand, M., Meyer, M.R., Beck, O. and Helander, A. (2018) Human Urinary Metabolic Patterns of the Designer Benzodiazepines Flubromazolam and Pyrazolam Studied by Liquid Chromatography-High Resolution Mass Spectrometry. Drug Testing and Analysis, 10, 496-506. https://doi.org/10.1002/dta.2243

[18] Salamone, S.J., Honasoge, S., Brenner, C., McNally, A.J., Passarelli, J., Goc-Szkutnicka, K., Brenneisen, R., El Sohly, M.A. and Feng, S. (1997) Flunitrazepam Excretion Patterns Using the Abuscreen OnTrak and OnLine Immunoassays: Comparison with GC-MS. Journal of Analytical Toxicology, 21, 341-345. https://doi.org/10.1093/jat/21.5.341

[19] Beck, O., Lin, Z., Brodin, K., Borg, S. and Hjemdahl, P. (1997) The Online Screening Technique for Urinary Benzodiazepines: Comparison with EMIT, FPIA, and GC-MS. Journal of Analytical Toxicology, 21, 554-557. https://doi.org/10.1093/jat/21.7.554

[20] Kuang, H., Li, Q., Shen, C., Xu, J., Yuan, Y., Xu, C. and Wang, W. (2009) A Highly Sensitive Method for the Determination of 7-Aminonitrazepam, a Metabolite of Nitrazepam, in Human Urine Using High-Performance Electrospray Liquid Chromatography Tandem Mass Spectrometry. Biomedical Chromatography, 23, 740-744. https://doi.org/10.1002/bmc.1178 


\section{Abbreviations}

CEDIA: Cloned Enzyme Donor Immunoassay.

EMIT: Enzyme-Multiplied Immunoassay Technique. 